\title{
Late Treatment of Zygomatic-Orbital Complex Fracture with a Combination of Surgical Approaches
}

\author{
Tratamiento Tardío de una Fractura del Complejo Cigomático-Orbitario \\ con una Combinación de Enfoques Quirúrgicos
}

\author{
Paola Fernanda Cotait de Lucas Corso*; Guilherme dos Santos Trento*; Diego José Stringhini*; \\ Delson João da Costa**; Nelson Luis Barbosa Rebellato**; Rafaela Scariot de Moraes ${ }^{* *}$ \& \\ Leandro Eduardo Klüppel**
}

CORSO, P. F. C. L.; TRENTO, G. S.; STRINGHINI, D. J.; COSTA, D. J.; REBELLATO, N. L. B.; SCARIOT, M. R. \& KLÜPPEL, L. E. Late treatment of zygomatic-orbital complex fracture with a combination of surgical approaches. Int. J. Med. Surg. Sci, 2(1):409-414, 2015.

SUMMARY: Zygomatic-orbital complex fractures are common in the middle face. As a protocol, it is necessary to establish an adequate exposure of the surgical site. The best surgical approach still remains a lot of controversy. However, the bicoronal flap is a versatile surgical technique to expose the craniofacial skeleton and allow an appropriate access to reduce and fix the fractured segments, being therefore a good alternative for the treatment. The association of other surgical approaches could promote better exposure of the fractured areas, turning an invasive procedure more complete and favorable. This article aims to report a case of zygomatic-orbital complex fractures and suggest a coronal approach along with others techniques to treat this kind of trauma. The great outcomes showed a satisfactory rehabilitation, fractures stabilized, favorable function and good aesthetic.

KEY WORDS: Zygomatic fractures; Orbital fractures; Facial injuries.

\section{INTRODUCTION}

The ideal surgical approach to treat craniomaxillofacial fractures should provide maximum exposure of the fractured segments, ensure less potential of injury to facial structures, in order to improve cosmetic results. Traditional closed techniques still compete with total exposure of all fracture lines by multiple incisions or coronal incision (Gruss et al., 1983, 1990; Frodel \& Marentette, 1993).

Trauma of the zygomatic complex constitutes $45 \%$ of all midface fractures according to Kovács \& Ghahremani (2001). This type of fracture usually involves the zygomatic arch, frontozygomatic suture, zygomatic butress and orbital floor. Some techniques show disadvantages like limited access to the fracture site, lack of adequate exposure, and subsequent facial scars. However, the bicoronal approach is widely used for craniofacial osteotomies and neurosurgical access to the intracranial contents (Jackson et al., 1982; Converse et al., 1977). This technique has become standard in neurosurgical, craniofacial, and cosmetic surgery. The entire upper face, including the zygoma, temporomandibular joint, orbital rims, and nasoetmoidal region, can be accessed through a coronal incision. When used in conjunction with subciliary and intraoral vestibular incisions, it provides optimum

* Resident of Oral and Maxillofacial Surgery at the Federal University of Parana, Curitiba/PR, Brazil.

** PhD, Professor of Oral and Maxillofacial Surgery at Federal University of Parana, Curitiba/PR, Brazil.

*** PhD, Chairman of Oral and Maxillofacial Surgery at Federal University of Parana, Curitiba/PR, Brazil. 
exposure and access to craniofacial and midfacial fractures. It also yields a superior long-term cosmetic result at the incision sites (Abubaker et al., 1990).

Complications of the coronal approach include temporary $(10-15 \%)$ or permanent $(2 \%)$ frontalis nerve injury, scalp sensory loss, temporal fossa depression, hair loss, and hematoma (Frodel \& Marentette).

The aim of this article is to describe a case of a female patient which had a zygomaticorbital complex fracture, that was treated through association of coronal, subciliary and intraoral approaches in order to access, reduce and stabilize the fracture.

\section{CASE REPORT}

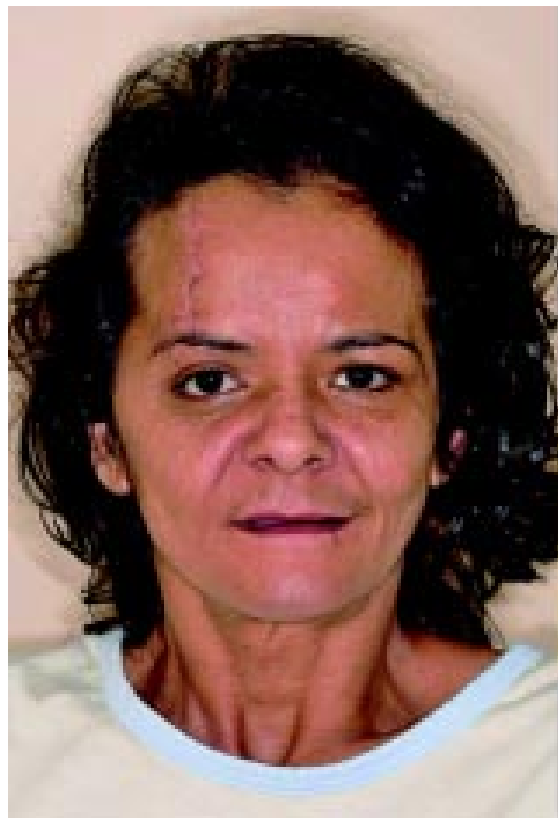

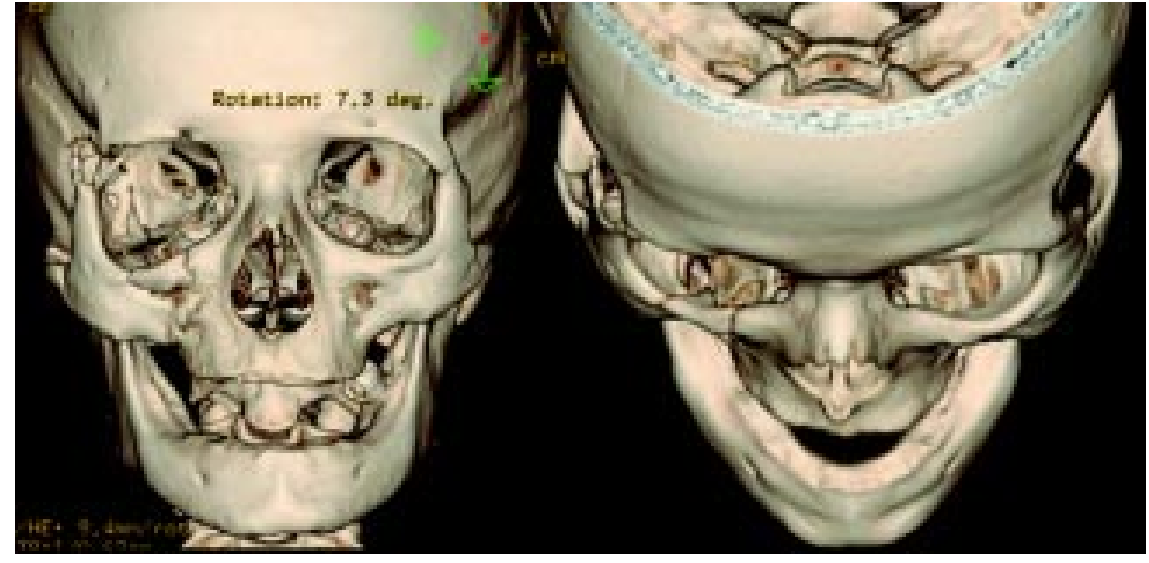

Fig. 2. Initial CT scan with the presence of fractures in the zygomaticorbital complex.

A 49-year-old, Caucasian female patient presented initially to the outpatient clinic 4 months after suffering a car accident, in which one she suffered cranio-encephalic traumatism, four left ribs fractured with left pulmonary perforation and fracture of the left femur and. Initially, the patient was examined and exploratory laparotomy was realized along with the cranial epidural hematoma drainage. Subsequently during a second visit the femur fracture reduction and fixation was performed, even though no surgical procedure to treat facial fractures was carried out.

The clinical features were dystopia, binocular diplopia (upper visual field), sinking into the malar region, enlargement of the right hemi-face, interference during mouth opening by the relationship between the zygomatic arch and the coronoid process movement, leading the patient to feeding difficulties and pain (Fig. 1). Through the computerized tomography was possible to verify the zygomatic complex involvement (Fig. 2). Comminuted fractures were present in the zygomatictemporal, zygomaticmaxillary and zygomaticfrontal sutures. Concerning orbit, it was possible to note the presence of blow-out fracture also involving the lateral wall.

The treatment for these complex fractures was planned by an association of surgical approaches. Under general

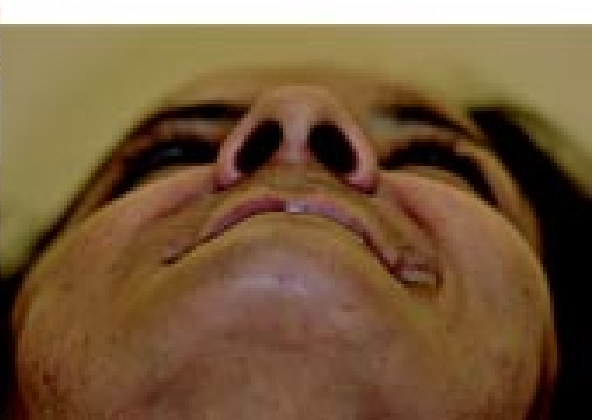

anesthesia, the coronal incision was performed at the scalp behind the hairline on both sides. On the left side the incision was extended preauricularly to provide access to the zygomatic arch, which was totally exposed from the subperiosteal dissection.

Fig. 1. Pre-operative aspect showing facial asymmetry. 
CORSO, P. F. C. L.; TRENTO, G. S.; STRINGHINI, D. J.; COSTA, D. J.; REBELLATO, N. L. B.; SCARIOT, M. R. \& KLÜPPEL, L. E. Late treatment of zygomatic-orbital complex fracture with a combination of surgical approaches. Int. J. Med. Surg. Sci., 2(1):409-414, 2015.

In association with this technique an intraoral access in a buccal maxillary mucosa was performed to access the zygomaticomaxillary pillar. Finally, a subciliary incision showed the comminuted fractures involving the infraorbital rim and orbital floor.

Stable internal fixation of the fracture sites was performed with 1.5 and $2.0 \mathrm{~mm}$ miniplates and screws. After that, reconstruction of the lateral orbital wall was performed with titanium mesh (Figs. 3 and 4). All the soft tissue was resuspended with resorbable suture. The patient was admitted in the ICU with drains and compressive dressing.

After a 6-month follow-up the patient showed a great improvement of right facial contour, no diplopia, no more interference in the mouth opening, and fractures stabilized (Figs. 5 and 6).

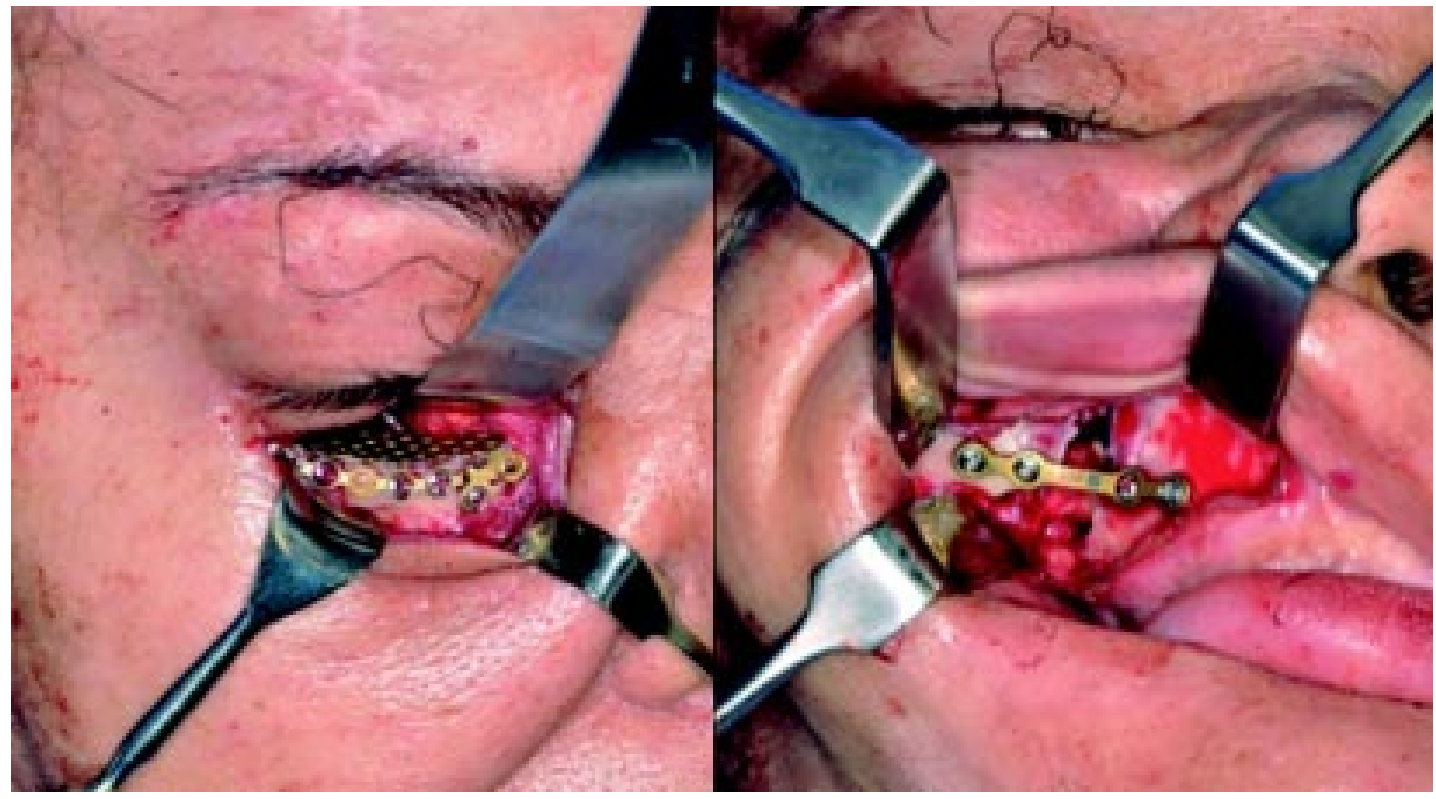

Fig. 3. Orbital and maxillary fixation with titanium mesh and plate respectively.

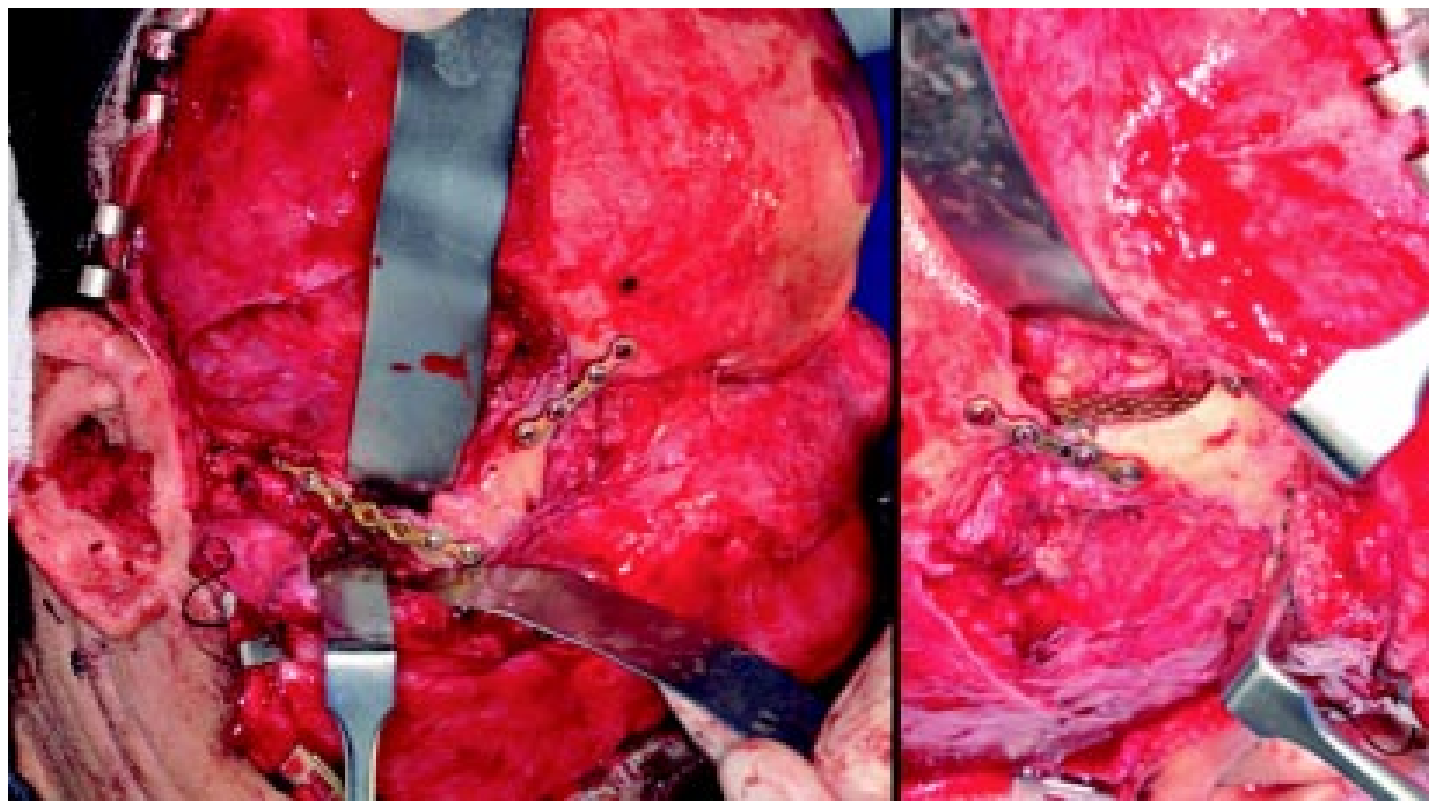

Fig. 4. A great exposure for zygomatic bone and infra-orbital rim reduction with titanium plate fixation. 


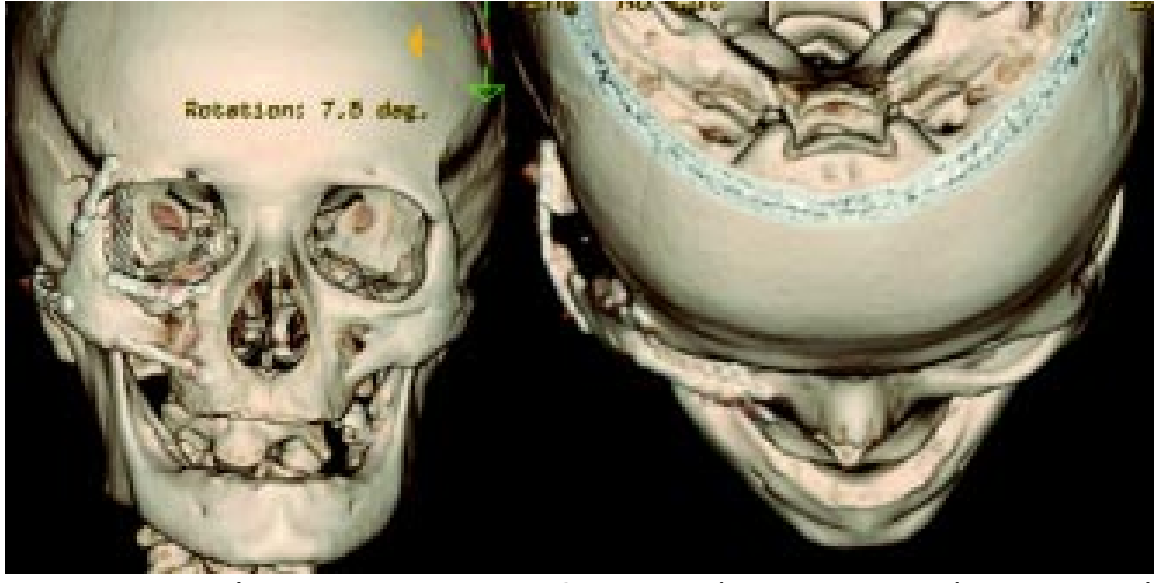

Fig. 5. Immediate postoperative CT scan showing a good anatomical replacement and fixation of the segments.

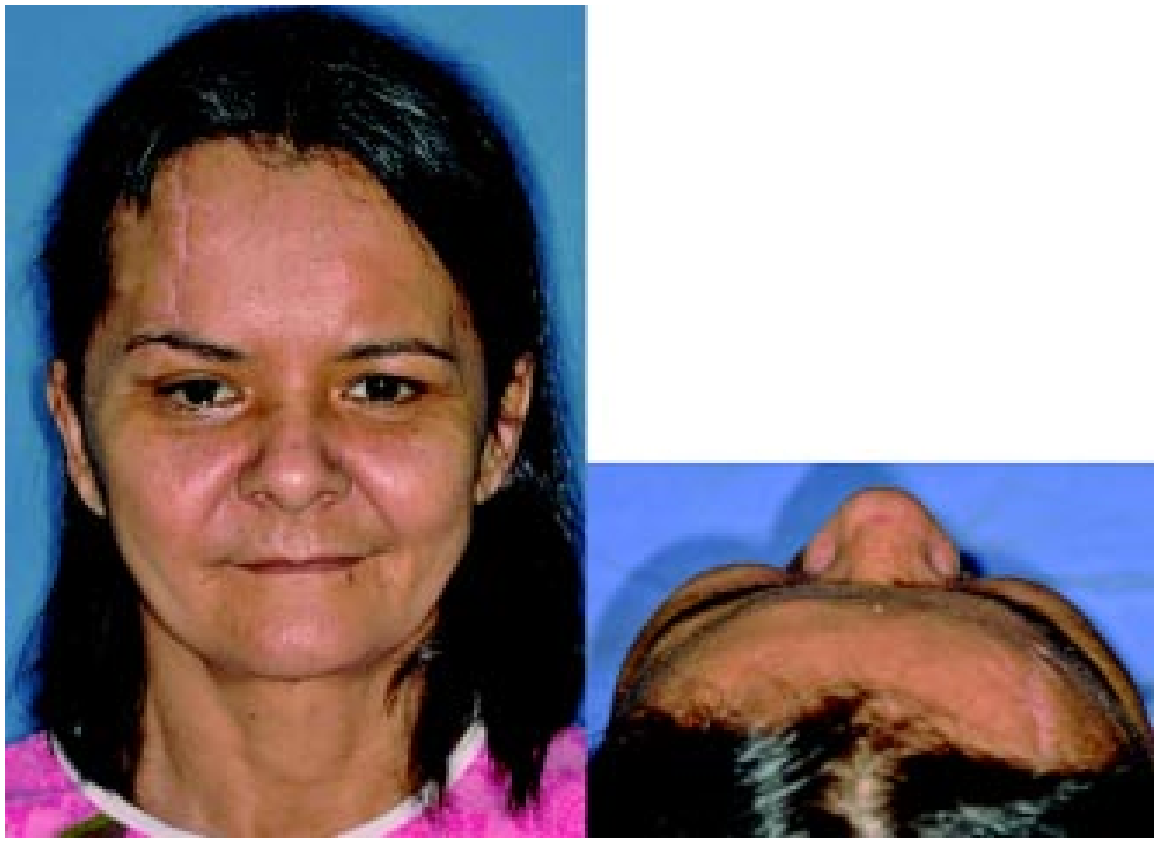

Fig. 6. Restoration of satisfactory facial contours with return of function.

the fragments by direct view and manipulation. One single approach is not always effective, unless the access is quite invasive, requiring further approaches be performed and all affected areas correctly accessed. The intraoral incision provided an optimal access with no visible scars, while subciliary access promoted good management to the infraorbital region although, there is a great discussion between transcutaneous and transconjunctival access. Whenever possible, all fractured fragments should be directly exposed. This allows for better assessment of the fractures and the degree of displacement, and it provides adequate access to accomplish anatomic reduction and fixation of the fractures (Abubaker et al.; Sebastiani et al., 2014).

Some studies have shown some comparison with aesthetic results between different techniques. The subciliary approach generally shows low rates of noticeable scars (Holtmann et al., 1981). About the intraoral approach, some authors suggest its use when the stability was not achieved (Kovács \&

\section{DISCUSSION}

When the zygomatic complex fractures involve orbital walls, reconstruction should reposition incarcerated or prolapsed orbital tissue from the fracture defect and span the bony defect with reconstructive implant materials associated with facial bone restoration with open reduction and internal fixation of fractured bone segments (Potter \& Ellis, 2004; Wilson \& Ellis, 2006). Through the surgical approaches described, it was possible to reduce and establish
Ghahremani, 2001). However, there is a controversy with respect to a multiple surgical approaches, consequent potential infections, additional scars, and nerve palsy. Nowadays these risks can be reduced with antibiotic medication.

The right diagnosis of fractures allows knowing if the large bone losses required bone grafts to be reconstructed through computed tomography (CT) images confirmation. Orbital traumas when improperly diagnosed or treated 
CORSO, P. F. C. L.; TRENTO, G. S.; STRINGHINI, D. J.; COSTA, D. J.; REBELLATO, N. L. B.; SCARIOT, M. R. \& KLÜPPEL, L. E. Late treatment of zygomatic-orbital complex fracture with a combination of surgical approaches. Int. J. Med. Surg. Sci., 2(1):409-414, 2015.

may lead to serious complications as diplopia, enophthalmos, restriction of eyeball mobility, disturbances in sensory innervations, and reduced globe motility. If the zygomatic arch is not correctly reduced, it could lead to inadequate facial contour and maintain the retention of the coronoid process (Kanno et al., 2010; Potter \& Ellis 2004). In this case the patient obtained the restoration of the facial contour and no orbital complications.

The patient looked for treatment just some months after suffering the accident, justifying the cause of her movement restriction, diplopia and dystopia. According to some authors who suggest that any visually handicapping diplopia or cosmetically unacceptable enophthalmos after 2 weeks will require surgery (Dortzbach \& Elner, 1987; Dulley \& Fells, 1974).

Numerous approaches and designs of surgical incisions have been used for the treatment of zygomaticomaxillary complex fractures. Scalp coronal incision is a common surgical approach for open reduction and stable internal fixation of zygomatic complex fractures compared with minimal incisions, especially for severely dislocated or complex fractures (Zhang et al., 2008). There is a divergence of currents as McLoughlin et al. (1994) that local incisions were preferred by $71 \%$. Kovács \& Ghahremani also prefer local incisions. Zhang et al. (2006) related more often use of coronal incisions for zygomatic complex fractures. In this case the choice for coronal access occurred namely due to comminuted fractures of the zygomatic arch which lead into a need of a large exposure in order to a correct reduce and stabilize segments.

Associating subciliary and intraoral vestibular incisions provide optimum exposure and access to craniofacial and midfacial fractures. Another advantage that can be widely considered is that most of the coronal incision line is hidden in the hairline, which provides a good cosmetic result (Turvey \& Fonseca, 1980; Abubaker et al.).

To avoid supraorbital nerve tearing, the flap was elevated until approximately $2 \mathrm{~cm}$ above the rims and was realized, by using a small drill around the foramen, an osteotomy through the supraorbital bundle to avoid injuries to the nerve and vascular components as well is described by Abubaker et al. and Shepherd et al. (1985).

\section{CONCLUSION}

The coronal access has been shown to be effective to expose, reduce and stabilize the zygomatic-orbital fractures. When associated with intraoral and subciliary access promoted a better exposure and management of the fractures. The precise indication to perform this technique should be evaluated, because it requires surgeon experience, caution and knowledge for being a complex approach technique.

CORSO, P. F. C. L.; TRENTO, G. S.; STRINGHINI, D. J.; COSTA, D. J.; REBELLATO, N. L. B.; SCARIOT, M. R. \& KLÜPPEL, L. E. Tratamiento tardío de una fractura del complejo cigomático-orbitario con una combinación de enfoques quirúrgicos. Int. J. Med. Surg. Sci., 2(1):409-414, 2015.

RESUMEN: Las fracturas del complejo cigomático-orbitario son comunes en la cara media. Como protocolo, es necesario establecer una adecuada exposición de la zona quirúrgica. El mejor abordaje quirúrgico sigue siendo de gran controversia. Sin embargo, la aleta bicoronal es una técnica quirúrgica versátil para exponer el esqueleto craneofacial y permitir un acceso adecuado para reducir y fijar los segmentos fracturados, siendo por lo tanto una buena alternativa para el tratamiento. La asociación de otros abordajes quirúrgicos podría promover una mejor exposición de las zonas fracturadas, convirtiéndose en un procedimiento invasivo más completo y favorable. Este artículo tiene como objetivo presentar un caso de fracturas del complejo cigomático-orbitario y sugerir un abordaje coronal, junto con otras técnicas para tratar este tipo de trauma. Los resultados mostraron una rehabilitación satisfactoria, fracturas estabilizadas, una función favorable y una buena estética.

PALABRAS CLAVE: Fracturas cigomáticas; Fracturas orbitales; Traumatismos faciales. 
CORSO, P. F. C. L.; TRENTO, G. S.; STRINGHINI, D. J.; COSTA, D. J.; REBELLATO, N. L. B.; SCARIOT, M. R. \& KLÜPPEL, L. E. Late treatment of zygomatic-orbital complex fracture with a combination of surgical approaches. Int. J. Med. Surg. Sci., 2(1):409-414, 2015.

\section{REFERENCES}

Abubaker, A. O.; Sotereanos, G. \& Patterson, G. T. Use of the coronal surgical incision for reconstruction of severe craniomaxillofacial injuries. J. Oral Maxillofac. Surg., 48(6):579-86, 1990.

Converse, J. M.; McCarthy, J. G.; Wood-Smith, D. \& Coccaro, P. J. Principles of craniofacial surgery. In: Converse, J. M. (Ed.). Reconstructive Plastic Surgery. Philadelphia, Saunders, 1977. pp.2427508.

Dortzbach, R. K. \& Elner, V. M. Which orbital floor blowout fractures need surgery? Adv. Ophthalmic Plast. Reconstr. Surg., 6:287-9, 1987.

Dulley, B. \& Fells, P. Orbital blow-out fractures: to operate or not to operate, that is the question. Br. Orthop. J., 31:47-54, 1974.

Frodel, J. L. \& Marentette, L. J. The coronal approach. Anatomic and technical considerations and morbidity. Arch. Otolaryngol. Head Neck Surg., 119(2):201-7, 1993.

Gruss, T. S. The use of craniofacial surgical techniques in the management of major cranio maxillofacial trauma. In: Jacobs, J. R. (Ed.). Maxillofacial trauma: an international perspective. New York, Praeger, 1983. pp. 22-32.

Gruss, J. S.; Van Wyck, L.; Phillips, J. H. \& Antonyshyn, $\mathrm{O}$. The importance of the zygomatic arch in complex midfacial fracture repair and correction of posttraumatic orbitozygomatic deformities. Plast. Reconstr. Surg., 85(6):878-90, 1990.

Holtmann, B.; Wray, R. C. \& Little, A. G. A randomized comparison of four incisions for orbital fractures. Plast. Reconstr. Surg., 67(6):731-7, 1981.

Jackson, I. T.; Munro, I. R.; Salyer, K. E. \& Whitaker, L. A. Atlas of Craniomaxillofacial Surgery. St. Louis, Mosby, 1982. pp.33-47.

Kanno, T.; Yamauchi, K.; Sukegawa, S.; Furuki, Y.; Masuda, T. Orbital floor reconstruction with anterior maxillary sinus wall for treatment of blowout fracture. Hosp. Dent. Oral Maxillofac. Surg., 22:105-9, 2010.

Kovács, A. F. \& Ghahremani, M. Minimization of zygomatic complex fracture treatment. Int. J. Oral Maxillofac. Surg., 30(5):380-3, 2001.
McLoughlin, P.; Gilhooly, M. \& Wood, G. The management of zygomatic complex fractures-results of a survey. Br. J. Oral Maxillofac. Surg., 3(5):284-8, 1994.

Potter, J. K. \& Ellis, E. Biomaterials for reconstruction of the internal orbit. J. Oral Maxillofac. Surg., 62(10): 1280-97, 2004.

Sebastiani, A. M.; Trento, G. S. ; Antonini, F.; Kluppel, L. E.; Scariot, R.; Costa, D. J.; Rebellato, N. L. B. Cicatricial ectropion correction in the inferior eyelid with cartilaginous tissue graft: Case report. Int. J. Med. Surg. Sci., 1(3):217-22, 2014.

Shepherd, D. E.; Ward-Booth, R. P. \& Moos, K. F. The morbidity of bicoronal flaps in maxillofacial surgery. Br. J. Oral Maxillofac. Surg., 23(1):1-8, 1985.

Turvey, T. A. \& Fonseca, R. J. Management of the soft tissues. In: Bell, W. H.; Proffit, W. R. \& White, R. P. (Eds.). Surgical Correction of Dentofacial Deformities. Philadelphia, Saunders, 1980. pp.13-4.

Wilson, S. \& Ellis, E. 3rd. Surgical approaches to the infraorbital rim and orbital floor: the case for the subtarsal approach. J. Oral Maxillofac. Surg., 64(1): 104-7, 2006.

Zhang, Q. B. ; Dong, Y. J.; Guan, J. B. ; Li, Z. B.; Zhao, J. H. \& Dong, F. S. Epidemiology and treatment of fractures of the zygomatic complex. Asian J. Oral Maxillofac. Surg., 20(2):59-64, 2008.

Zhang, Q. B.; Dong, Y. J.; Li, Z. B. \& Zhao, J. H. Coronal incision for treating zygomatic complex fractures. J. Craniomaxillofac. Surg., 34(3): 182-5, 2006.

Correspondence to:

Paola Fernanda Cotait de Lucas Corso

632th Prefeito Lothário Meissner Avenue

Curitiba, Parana

ZIP CODE 80310-410

BRAZIL

Email: paolafcorso@gmail.com

Received: 26-02-2015

Accepted: 24-03-2015 